\title{
Biodiversity: crises past and present, and future challenges
}

\author{
This article was published in the following Dove Press journal: \\ Research and Reports in Biodiversity Studies \\ 2I June 20II \\ Number of times this article has been viewed
}

\section{David JW Lane}

Department of Biology, Universiti Brunei Darussalam, Brunei

Darussalam
Correspondence: David JW Lane

Department of Biology, Universiti Brunei

Darussalam, Jalan Tungku Link,

Gadong BEI410, Brunei Darussalam

Tel +673246300 I ext I 378

Fax +6732461502

Email david.lane@ubd.edu.bn
This inaugural issue of a new biodiversity journal, Research and Reports in Biodiversity Studies (RRBS), is one of many new scientific Journals that are appearing and competing for ratings in the academic arena. Librarians, institutes of higher education, and funding agencies might despair of being able to source the funding needed to sustain institutional subscriptions or authorship fees for new journals, yet, as indicated below, there has never, unfortunately, been a greater need for advancing and reporting knowledge of biodiversity, its preservation, and its presentation to a wide audience. Open-access journals, such as this one, provide an ideal platform for alerting the scientific and media world to biodiversity issues and the growing threats to the world's living heritage. RRBS, with its open-access, electronic format, has several advantages over traditional subscription-based journals for disseminating new ideas, discoveries, and status reports on biodiversity. For example, while maintaining quality of peer review, throughput times are rapid, articles are not rejected due lack of space, and (being online) expensive production costs for graphics are virtually eliminated. And, of course, articles have free, unrestricted access. This niche in the publishing world and RMBR, specifically, consequently provides a much-needed venue for perhaps one of the most important topics for all humanity today - that of biodiversity.

The range of life forms that have evolutionarily diversified and proliferated in spectacular profusion on planet Earth - possibly uniquely in the universe - has currently attained arguably the highest level of complexity, richness, and interrelatedness ever recorded ${ }^{1-4}$ since its origin some 3.8 billion years ago, or possibly earlier. ${ }^{5}$ This procession and accumulation of life has by no means been a gradual or directed progression but one interrupted by catastrophic extinction events - five major and many minor ones - that, each time, wiped out a high proportion of species, yet subsequently has led over millions of years to evolutionary proliferation in new directions, including, paradoxically (from our own viewpoint), our own remote mammalian ancestors.

The best data for past biodiversity extinction events and rates are derived from the fossil record of marine skeletogenous animals, ${ }^{2,6}$ while the interest in contemporary extinctions focuses largely on terrestrial organisms. This makes comparisons difficult, yet the general consensus is that organic diversity, from species to ecosystem level, is currently under threat and that we are perhaps witnessing the beginnings of a sixth major extinction event, sometimes termed the Holocene extinction crisis. Some argue that there is little evidence, yet, for high rates of extinction (eg, Stork ${ }^{7}$ ) and certainly the perception by the general populace of species losses and environmental degradation tends to be masked by its incremental nature - the phenomenon of creeping normalcy. ${ }^{8}$ However there 
is little doubt that diversity and habitat losses at all levels are escalating $^{9}$ and that the threats to biodiversity and the natural environment are largely due to a rapidly burgeoning human population. Thomas Malthus, ${ }^{10}$ writing his essay on human population at the beginnings of the industrial and agricultural revolution, was a little premature in the predicted timing of this scenario, but the ever-growing numbers of humans today are directly destroying or expropriating natural habitats for human use and overexploiting living resources, or indirectly impacting biodiversity (negatively) through global anthropogenic effects on climate patterns. Almost one-quarter of net primary production on land has been appropriated by humans ${ }^{11}$ with consequential effects on biogeochemical cycles, ecosystem services, and biodiversity. Ocean ecosystems, too, have been radically transformed; almost $80 \%$ of the world's fisheries are overexploited, or in a state of collapse, with most large predatory fish gone and fisheries characterized by fishing at lower levels in food webs. ${ }^{12}$ A recent global appraisal of biodiversity ${ }^{13}$ found that most indicators of the state of biodiversity show declines with no significant slowing of rates, and indicators of pressure showing increases.

Many small organisms, particularly generalist species (including pests such as cockroaches and many rodents), would undoubtedly survive and adapt (and evolve) in degraded or changed environments, but highly specialized organisms (think of the horseshoe bat that "invented" a form of "radar" some 50 million years before human engineers did, or intricate interrelationships such as those of hummingbirds or bee pollinators with plants) are vulnerable and increasingly at risk of extinction. Species that have evolved as "special editions" on islands are particularly susceptible to depredations, or to being outcompeted by invasives, be they human, animal, or plant. ${ }^{14}$ Large organisms in particular, including sustainable populations of our own species, owe their very existence to the biological diversity of food webs that they depend upon. Biodiversity is the key to maintenance of the world as we know it; including the health benefits that undisturbed ecosystems provide, the role that biodiversity plays in providing ecosystem services, and food security for humankind. Many people living on this planet today have seen the human population double during their own lifetime and some have seen it triple. ${ }^{15}$ The consequential pressures and threats of this "epidemic" population explosion on living resources are very real. Mitigation efforts need to be based on up-to-date primary information, and this new journal provides an ideal platform, with rapid reporting and appraisal of biodiversity issues, and highlighting strategies for maintenance of the richness of the Earth's living resources upon which all of us, and our descendants, ultimately depend.

\section{References}

1. Signor PW. Biodiversity in geological time. Am Zool. 1994;34: 23-32.

2. Solé RV, Newman M. Patterns of extinction and biodiversity in the fossil record. In: Mooney HA, Canadell GJ, editors. The Earth System: Biological and Ecological Dimensions of Global Environmental Change. Vol 2. J. Wiley \& Sons. Ltd; 2002:297-301.

3. Crame JA, Rosen BR. Cenozoic palaeogeography and the rise of modern biodiversity patterns. In: Crame JA, Owen AW, editors. Palaeobiogeography and Biodiversity Change: the Ordovician and Mesozoic-Cenozoic Radiations. Special Publications 194. London: Geological Society; 2002:153-168.

4. Kroh A, Smith AB. The phylogeny and classification of post-Palaeozoic echinoids. Journal of Systematic Palaeontology. 2010;8:147-212.

5. Abromov O, Mojzsis SJ. Microbial habitability of the hadean Earth during the late heavy bombardment. Nature. 2009;459:419-422.

6. Raup DM. Extinction: Bad Genes or Bad Luck? New York, London: W.W. Norton \& Company; 1991.

7. Stork NE. Re-assessing current extinction rates. In: Lane DJW, editor. Tropical Islands Biodiversity Crisis: The Indo-West Pacific. Topics in Biodiversity and Conservation. Vol. 13. Dordrecht, Heidelberg, London, New York: Springer; 2010.

8. Diamond J. Collapse: How Societies Choose to Fail or Succeed. New York: Viking; 2005.

9. IUCN. Wildlife in a Changing World: An Analysis of the 2008 Red List of Threatened Species. Vié J-C, Hilton-Taylor C, Stuart SN, editors. Gland: IUCN; 2009.

10. Malthus TR. An Essay on the Principle of Population as it Affects the Future Improvement of Society. London: J. Johnson; 1798.

11. Haberl H, Eb KH, Kraussmann F, et al. Quantifying and mapping the human appropriation of primary productivity in earth's terrestrial ecosystems. Proc Natl Acad Sci U S A. 2007;104:12942-12947.

12. Pauly D, Palomares M-L. Fishing down marine food webs: it is far more pervasive than we thought. Bulletin of Marine Science. 2005;76: 197-211.

13. Butchart SHM, Walpole M, Collen B, et al. Global biodiversity: indicators of recent declines. Science. 2010;328:1164-1168.

14. Lane DJW, editor. Tropical Islands Biodiversity Crisis: The Indo-West Pacific. Topics in Biodiversity and Conservation, Vol. 13. Dordrecht, Heidelberg, London, New York: Springer; 2010.

15. Hern WM. How many times has the human population doubled? Comparisons with cancer. Population and Environment: A Journal of Interdisciplinary Studies. 1999;21:59-80.
Research and Reports in Biodiversity Studies

\section{Publish your work in this journal}

Research and Reports in Biodiversity Studies is an international, peerreviewed, open access journal publishing original research, reports, reviews and commentaries on all areas of biodiversity research. The manuscript management system is completely online and includes a very quick and fair peer-review system. Visit http://www.dovepress.com/ testimonials.php to read real quotes from published authors. 